\title{
Trabzon'da 20 Yaş ve Üzeri Bireylerde Toksoplazmoz Seroprevalansı
}

\section{Seroprevalence of Toxoplasmosis among 20 Years and Older Individuals in Trabzon, Turkey}

\author{
Serdar KARAKULLUKÇU ${ }^{1}\left(\right.$ ID), Nazım Ercüment BEYHUN ${ }^{2}(I D)$, Neşe KAKLIKKAYA ${ }^{3}($ ID), \\ iftihar KÖKSAL ${ }^{4}(I D)$, Murat TOPBAŞ ${ }^{2}(I D)$, Celal Kurtuluş BURUK ${ }^{3}$ (ID), Gamze ÇAN ${ }^{5}$ (ID), \\ Mustafa YILMAZ ${ }^{6}(I D)$, Köksal HAMZAOĞLU(ID), Esin $\operatorname{SAYIN}^{7}\left(\right.$ ID), Cevriye Ceyda KOLAYLI ${ }^{8}(I D)$ \\ ${ }^{1}$ Bayburt Toplum Sağlığı Merkezi, Bayburt. \\ ${ }^{1}$ Bayburt Community Health Center, Bayburt, Turkey. \\ ${ }^{2}$ Karadeniz Teknik Üniversitesi Tıp Fakültesi, Halk Sağlığı Anabilim Dalı, Trabzon. \\ 2 Karadeniz Technical University Faculty of Medicine, Department of Public Health, Trabzon, Turkey. \\ ${ }^{3}$ Karadeniz Teknik Üniversitesi Tıp Fakültesi, Mikrobiyoloji ve Klinik Mikrobiyoloji Anabilim Dalı, Trabzon. \\ ${ }^{3}$ Karadeniz Technical University Faculty of Medicine, Department of Microbiology and Clinical Microbiology, Trabzon, \\ Turkey. \\ ${ }^{4}$ Acıbadem Sağlık Grubu, Enfeksiyon Hastalıkları ve Klinik Mikrobiyoloji Anabilim Dalı, İstanbul. \\ ${ }^{4}$ Acibadem Health Group Department of Infectious Disease and Clinical Microbiology, Istanbul, Turkey. \\ ${ }^{5}$ Çanakkale Onsekiz Mart Üniversitesi Tıp Fakültesi, Halk Sağlığı Anabilim Dalı, Çanakkale. \\ ${ }^{5}$ Canakkale Onsekiz Mart University Faculty of Medicine, Department of Public Health, Canakkale, Turkey. \\ ${ }^{6}$ Karadeniz Teknik Üniversitesi Tıp Fakültesi, İç Hastalıkları Anabilim Dalı, Trabzon. \\ ${ }^{6}$ Karadeniz Technical University Faculty of Medicine, Department of Internal Medicine, Trabzon, Turkey. \\ 7 Trabzon il Sağlık Müdürlüğü, Trabzon. \\ 7 Trabzon Provincial Directorate of Health, Trabzon, Turkey. \\ ${ }^{8}$ Ardahan il Sağlık Müdürlüğü, Ardahan. \\ ${ }^{8}$ Ardahan Provincial Directorate of Health, Ardahan, Turkey.
}

Makale Atıfı: Karakullukçu S, Beyhun NE, Kaklıkkaya N, Köksal i, Topbaş M, Buruk CK ve ark. Trabzon'da 20 yaş ve üzeri bireylerde toksoplazmoz seroprevalansı. Mikrobiyol Bul 2021;55(2):233-247.

\section{öz}

Toxoplasma gondii, dünya çapında en yaygın zoonotik parazitlerden biridir. Bağışıklık sistemi sağlam bireylerde enfeksiyonun büyük oranda asemptomatik geçirilmesi, hastalığın farkında olmadan geçirilmesine ve göz ardı edilmesine sebep olmaktadır. Bu çalışmada, 20 yaş ve üzeri bireylerde toksoplazmoz seroprevalansının ve seroprevalans ile ilişkili faktörlerin tespit edilmesi amaçlanmıştır. Kesitsel tipteki bu çalışma, 20 yaş ve üstü bireylerin katılımıyla Türkiye'nin yüksek nüfuslu bir kenti olan Trabzon'da gerçekleştirilmiştir. Hesaplanan örneklem büyüklüğü \%50 bilinmeyen prevalans, \%3 sapma, bir desen etkisi ile 1066 kişidir. Çalışmada kırsal-kentsel, cinsiyet ve yaşa göre tabakalandırma yapıldığı için \%40 fire olma olasılığı eklenerek 1500 kişiye ulaşılması hedeflenmiş, toplamda 1502 kişiye ulaşılmıştır. Saha çalışması iki aşamada gerçekleştirilmiştir. ìlk aşamada hane ziyaretleri gerçekleştirilmiş, yüz yüze anket uygulanmıştır. İkinci aşamasında ise anti-Toxoplasma antikorlarını saptayabilmek amacıyla kan alımı işlemi gerçekleştirilmiştir. Serum örneklerinde elektrokemilüminesans immunoassay (ECLIA) yöntemi ile anti-Toxoplasma lgG ve IgM antikorlarının varlığı ve düzeyi araştırılmıştır. Araştırma kapsamında katılımcıların $767(\% 51.1)^{\prime}$ si 
kadın, 735 (\%48.9)'i erkek olup, yaş ortalamaları $45.7 \pm 16.9$ yıldır. Katılımcıların \%58.8'inde anti-Toxoplasma gondii IgG, \%2.3'ünde anti-Toxoplasma gondii IgM seropozitifliği saptanmıştır. Yaş ve vücut kitle indeksi arttıkça toksoplazmoz seroprevalansının arttığı, gelir arttıkça ise seroprevalansın düştüğü gözlenmiş̧ir. Bahçe ve tarla işleri ile uğraşanlarda, hayvancılık yapanlarda, kırsal ilçelerde ikamet edenlerde, medeni durumu evli olanlarda, eğitim düzeyi ilkokul ve altı olanlarda, riskli meslek sahiplerinde, diyabet hastalığı olanlarda ve psikiyatrik rahatsızlığı olanlarda seropozitiflik istatistiksel olarak önemli düzeyde yüksek bulunmuştur. Çiğ et ve süt, yıkanmamış sebze ve meyve tüketimi olanlarda, kedi besleyenlerde ve işlenmemiş su kullananlarda seropozitiflik açısından önemli bir fark saptanmamıştır. Lojistik regresyon modelinde yaş $(\mathrm{OR}=1.05 ; \% 95 \mathrm{GA}=1.04-1.06)$ ve bahçe ve tarla işleriyle uğraşmanın $(\mathrm{OR}=1.31 ; \% 95$ $\mathrm{GA}=1.03-1.67)$ bağımsız risk faktörü olduğu, eğitim durumunun ilkokul ve altı olmasının $(\mathrm{OR}=1.41$; \%95 GA= 1.07-1.86) riski artıııc faktör olduğu tespit edilmiştir. Çalışmamızda, anti-Toxoplasma gondii seropozitifliği dünyada ve Türkiye'de yapılan çalışmalara göre görece yüksek bulunmuştur. Bahçe ve tarla işleriyle uğraşan insanlar toksoplazmoz konusunda bilinçlendirilmelidir. Diyabetik ve psikiyatrik hastalığı olanlarda toksoplazmozun daha sık görülebildiği klinisyenlerce dikkate alınmalıdır.

Anahtar kelimeler: Toxoplasma gondii; toksoplazmoz; seroprevalans; toplum; Türkiye.

\section{ABSTRACT}

Toxoplasma gondii is one of the most prevalent zoonotic parasites. The fact that the infection is mostly asymptomatic in immunocompromised individuals causes the disease to be recovered without realising and ignored. The aim of this study was to determine the seroprevalence of toxoplasmosis and the factors associated with seroprevalence in individuals aged 20 and over. This cross-sectional study was conducted in Trabzon which is a high populated city of Turkey with the participation of individuals aged 20 and over. The calculated sample size including 50\% unknown prevalence, $3 \%$ deviation and one pattern effect was 1066 people. Since the rural-urban, gender and age stratification was performed in the study, the goal was to reach 1500 people by adding the possibility of $40 \%$ loss and finally a total of 1502 people were reached. Field research was carried out in two stages. First, household visits were conducted and face-to-face interviews were performed. Then, blood samples were collected to determine anti-Toxoplasma antibodies. The presence and the level of anti-Toxoplasma $\lg G$ and $\operatorname{lgM}$ antibodies were detected in serum samples by using the electrochemiluminescence immunoassay (ECLIA) method. In the scope of the research, 767 $(51.1 \%)$ of the participants were women and $735(48.9 \%)$ of them were men and their average age was $45.7 \pm 16.9$ years. Anti-Toxoplasma gondii $\operatorname{lgG}$ and $\operatorname{lgM}$ seropositivity among the participants were $58.8 \%$ and $2.3 \%$, respectively. It was observed that seroprevalence of toxoplasmosis increased as age and body mass index increased and as the income increased seroprevalence decreased. Seropositivity was found to be statistically significantly higher in those who were working in gardening and field work, those who were working in animal husbandry, those who resided in rural districts, those whose marital status was married, those whose education level was primary school or below, those who had high-risk professions, those with diabetes and those with psychiatric disorders. There was no significant difference in seropositivity among those who ate raw meat and milk, unwashed fruit and vegetables, cat owners and used unprocessed water. In the logistic regression model, it was determined that age $(\mathrm{OR}=1.05 ; 95 \% \mathrm{Cl}=1.04-1.06)$ and working in gardening and field work $(\mathrm{OR}=1.31 ; 95 \% \mathrm{Cl}=1.03-1.67)$ were independent risk factors and education status of primary school and below ( $\mathrm{OR}=1.41 ; 95 \% \mathrm{Cl}$ : $1.07-1.86)$ was a risk-increasing factor. In our study, anti-Toxoplasma gondii seropositivity was found to be relatively higher compared to the other studies conducted in the world and Turkey. Awareness of individuals working in gardening and field work about toxoplasmosis must be enhanced. Clinicians must consider the fact that toxoplasmosis can be more frequently observed in individuals with diabetes and psychiatricdisorders.

Keywords: Toxoplasma gondii; toxoplasmosis; seroprevalence; community; Turkey.

\section{Gíriş}

Toxoplasma gondii, insanlarda genellikle asemptomatik enfeksiyona neden olan, ancak konjenital olarak enfekte bebeklerde ve immün yetmezliği olan hastalarda önemli hastalıklara neden olabilen koksidiyan protozoondur. Bu protozoonun sebep olduğu toksoplazmoz, tüm dünyada yaygın olarak rastlanan, paraziter bir enfeksiyon hastalığıdır ${ }^{1}$. 
Toxoplasma gondii'nin kesin konağı kedi ve kedigiller, ara konağı ise insan dahil tüm memeli ve kanatlı hayvanlardır². Bu parazitin yaşam döngüsünde konak türüne ve enfeksiyon dönemine göre değiş̧en üç ayrı enfektif form bulunmaktadır. Bu formlar takizoit, bradizoit (doku kisti içinde) ve ookist formlarıdır. Ookist formları sadece kedilerde şekillenirken, takizoit ve bradizoitler kedi dahil tüm ara konaklarda oluşabilmektedir ${ }^{3}$. Kedilerin dışkılarını gömme alışkanlıkları ookistlerin direkt güneş ışığına maruz kalmasını, kurumasını önlemekte ve parazitin neslinin doğada devamına katkıda bulunmaktadır ${ }^{4}$.

Insanlarda enfeksiyon, yaygın olarak doku kistlerini içeren çiğ veya az pişmiş etlerin yenmesiyle veya ookistle kontamine su ve yiyeceklerin tüketilmesiyle meydana gelmektedir. Daha az sıklıkta ise enfekte anneden transplasental bulaş, enfekte organın nakli veya laboratuvar kazası ile ortaya çıkabilmektedir. Insandan insana bulaşma sadece hamilelikte fetüse bulaşma ile olmaktadır ${ }^{1}$.

İmmün sistemi sağlam bireylerde enfeksiyonun büyük oranda asemptomatik geçirilmesi hastalığın farkında olmadan geçirilmesine ve göz ardı edilmesine neden olmaktadır. Etkenin gebe kadınlarda plasental geçiş göstererek konjenital toksoplazmoza, immün yetmezliği olan bireylerde ciddi nörolojik bulgularla ölümlere, sağlıklı kiş̧ilerde ise akut dissemine toksoplazmoza neden olabilmesi enfeksiyonun bir halk sağlığı sorunu olduğunu ortaya koymaktadır ${ }^{5}$.

Toksoplazmoz prevalansı yaşam tarzına, alışkanlık ve geleneklere, parazitin virülansına, konağın yaşına, duyarlılığına, immünitesine ve coğrafik bölgelere göre farklılıklar göstermektedir. Örneğin; soğuk bölgelere nazaran sıcak ve nemli yerlerde; şehirlere göre kırsal kesimde ve normal popülasyona göre hayvanlarla ilişkisi olan kişilerde prevalansın yüksek olduğu bildirilmektedir ${ }^{6}$.

Dünya nüfusunun yaklaşık üçte birinin T.gondii ile enfekte olduğu tahmin edilmekte$\operatorname{dir}^{6,7}$. Bu oran; iklim, beslenme ve hijyen alışkanlıklarındaki farklılıklar nedeniyle ülkelere ve bölgelere göre büyük oranda değişmektedir. Son yıllarda yapılmış bir derlemede, dünya çapında anti-T.gondii seropozitifliği \%25.7 olarak tespit edilmiştir. En yüksek ortalama seroprevalans oranı \%61.4 ile Afrika ülkelerinde olurken, bu ülkeleri \%38.5 ile Okyanusya, \%31.2 ile Güney Amerika, \%29.6 ile Avrupa, \%17.5 ile ABD/Kanada ve \%16.4 ile Asya'nın izlediği görülmüştür ${ }^{7}$. Türkiye'de yapılan çalışmaların çoğunluğunu gebeler gibi risk gruplarını içeren ve hastane tabanlı yapılan çalışmalar oluşturmaktadır. Gebelerde seroprevalans verilerinin derlendiği bir meta-analizde, Türkiye'deki gebelerde anti-Toxoplasma gondii seropozitifliği \%35.8 olarak saptanmıştır ${ }^{8}$. Çoğunlukla hastaneye başvuranların ve hamile kadınların örneklem olarak kullanıldığı başka bir derlemede, anti-Toxoplasma gondii seropozitifliğinin \%18-100 arasında değiştiği saptanmıştır ${ }^{9}$. İzmir'de küçük bir bölgede yapılan toplum tabanlı çalışmada ise toksoplazmoz seroprevalansı 7-50 yaş grubunda \%30 olarak bulunmuştur ${ }^{10}$.

Bütün risk faktörlerinin bir arada değerlendirildiği, geniş örneklemle yapılan toplum tabanlı bir çalışmaya literatürde rastlanmamıştır. Bu nedenle çalışmamızda 20 yaş ve üzeri bireylerde toksoplazmoz seroprevalansının tespit edilmesi ve seroprevalansla ilişkili olabilecek faktörlerin değerlendirilmesi amaçlanmıştır. 


\section{GEREÇ ve YÖNTEM}

Bu çalışma, Karadeniz Teknik Üniversitesi Tıp Fakültesi Bilimsel Araştırmalar Etik Kurulu onayı ile gerçekleştirildi (Tarih: 05.12.2017 ve Karar No: 164). Araştırma hakkında gerekli bilgilendirmeler yapıldıktan sonra araştırmaya katılmayı kabul eden katılımcılara "Bilgilendirilmiş Gönüllü Onam Formu" imzalatılarak yazılı onamları alınmıştır. Araştırmanın saha çalışmasının ikinci aşaması olan kan alım işlemleri sağlık kurumlarında gerçekleştirildiğinden çalışma öncesi Trabzon II Sağlık Müdürlüğü ile çalışmanın yürütüldüğü Karadeniz Teknik Üniversitesi Tıp Fakültesi Halk Sağlığı Anabilim Dalı arasında iş birliği protokolü imzalanmıştır. Ayrıca araştırmanın ilk aşamasında hane ziyaretleri yapıldığından ilin mülki amiri konumunda olan valilik makamının da oluru alınmıştır.

\section{Çalışmanın Tipi ve Yeri}

Kesitsel araştırma olarak planlanmış olan bu çalışma, Türkiye'nin yüksek nüfusa sahip illerinden biri olan Trabzon ilinde gerçekleştirilmiştir. Oldukça nemli bir iklime sahip Trabzon'da, nem oranı zaman zaman \%99'lara kadar çıkmaktadır. Yılık ortalama yağış miktarı 800-850 kg/m² civarındadır.

Araştırmanın evrenini Türkiye İstatistik Kurumunun (TÜiK) 2017 nüfus verilerine göre ilde ikamet eden 20 yaş ve üzeri bireyler oluşturmaktadır. Örneklem büyüklüğünü hesaplamada Open Epi programı kullanıldı. Hesaplanan örneklem büyüklüğü \%50 bilinmeyen prevalans, \%3 sapma, bir desen etkisi ile 1066 kişidir. Çalışmada kırsal-kentsel, cinsiyet ve yaşa göre tabakalandırma yapıldığı için fire olma olasılığı \%40 alındı. Hesaplanan örneklem büyüklüğü 1066'ya \%40 fire olma olasılığı da eklenerek 1500 kişiye ulaşılması hedeflendi. Araştırma için 2638 kişiyle görüşme yapıldı; bu kişilerden 835'i araştırmaya katılmayı reddetti; 255 kişi yaş ve cinsiyet açısından tabakalamaya uygun olmadığı için çalışmaya alınamadı; 46 kişi çalışmaya katılmayı kabul etmesine rağmen kan alım işlemine gelmedi. Çalışmanın tüm aşamalarına 1502 kişi katıldı.

Araştırma kapsamında kentsel ve kırsal bölgeler dikkate alınarak toplam 10 ilçeye gidildi. Çalışmanın örneklem seçiminde tabakalı örnekleme yöntemi kullanılarak örneklem belirlenen ilçelere ve mahallelere dağıtıldı.

\section{Anket}

Anket formu katılımcıların sosyodemografik özellikleri ve alışkanlıkları, toksoplazmoz ile ilgili bağışıklık durumları, toksoplazmoz enfeksiyonu ile ilişkili faktörleri ve kadın katılımcıların gebelikleriyle ilgili özelliklerini sorgulayan dört bölüm halinde sunuldu. Sosyodemografik özelliklerin sorgulandığı birinci bölümde katılımcının adı soyadı, yaşı, cinsiyeti, medeni durumu, eğitim durumu, mesleği, gelir getiren bir işte çalışma durumu, ailesinin aylık toplam geliri, evde yaşayan kişi sayısı, evinde kaç oda bulunduğu, boyu ve kilosuyla ilgili bilgileri alındı. Alışkanlıklarının sorgulandığı bölümde sigara ve alkol kullanım durumlarına yönelik sorular bulunmaktadır. Katılımcıların bazı sağlık durumlarının sorgulandığı ikinci bölümde, kanser, diyabetes mellitus, obezite, psikiyatrik hastalık varlığı, immünsupresif ilaç kullanımı, kemoterapi ve radyoterapi uygulanması, diyaliz tedavisi 
alma gibi durumları sorgulandı. Toksoplazmoz ile ilgili bağışıklık durumunun sorgulandığı üçüncü bölüm ile toksoplazmoz ilişkili faktörlerin sorgulandığı; dördüncü bölümde evde evcil hayvan besleme, sokak hayvanlarıyla temas gibi durumların varlığı, çiğ et, süt, ve sebze gibi besin maddelerini tüketim durumu, meyve ve sebzeleri yemeden önce yıkama durumları, içme ve genel kullanım amaçlı tercih ettikleri su çeşidi, köy/yayla gibi kırsal alana gitme durumları, amaçları ve sıklıkları, bahçe/tarla işleriyle uğraşma ile hayvancılıkla uğraşma durumlarıyla ilgili bilgiler yer almaktaydı.

Saha çalışması iki aşamada yürütüldü. İlk aşamada hane ziyaretleri yapıldı, çalışmanın amacı anlatıldı ve katılımcıların onayı alındı. Çalışmayı kabul eden katılımcılara anket uygulamasının ardından ikinci aşamada katılımcılar Aile Sağlığı Merkezlerine davet edilerek kan alım işlemi gerçekleştirildi.

\section{Kan Örneği Toplanması ve Serolojik Testler}

Saha çalışmasında kan örneği toplanması Nisan 2018-Haziran 2018 tarihleri arasında gerçekleştirildi. Anti-Toxoplasma antikorları için 5 ml'lik jelli vakumlu kan tüpüne alınan kan örnekleri, 20 dakika 4000 devirde santrifüj edilerek serum örnekleri elde edildi. Bu örnekler, analiz edilinceye kadar $-40^{\circ} \mathrm{C}^{\prime}$ de saklandı. Anti-Toxoplasma lgG ve Toxoplasma IgM antikorlarının varlığı ve düzeylerinin belirlenmesi amacıyla elektrokemilüminesans immuno assay (ECLIA) yöntemi ile çalışan Elecsys Toxo IgG ve Elecsys Roche Toxo IgM kitleri (Roche Diagnostics, Mannheim, Almanya) kullanıldı; testler Cobas 6000 e601 analizöründe, firmanın önerileri doğrultusunda çalışıldı. Sonuçlar, Tablo I'de belirtilen referans aralıklarına göre yorumlandı.

Katılımcıların Anti-Toxoplasma-lgG ya da IgM antikorlarından herhangi birine sahip olması seropozitiflik olarak değerlendirildi. Anti-Toxoplasma-lgM antikorlarının bazı vakalarda kronik enfeksiyonu göstermesi nedeniyle, sadece iki katılımcıda tekli Anti-ToxoplasmaIgM pozitifliğinin bulunması üzerine bu tercih yapıldı ${ }^{11}$.

\section{Verilerin Kategorizasyonu}

Katılımcıların beyan ettiği ailelerinin aylık toplam geliri sınıflandırılırken ortanca değeri dikkate alındı. Ortanca değer ve altı, ortanca değerin üstü olmak üzere 2 gruba sınıflandırıldı.

Meslekler, ISCO-08 (International Standard Classification of Occupations)'e göre kategorize edildi. Karşılaştırmalı istatistiklerde Toxoplasma enfeksiyonu açısından riskli meslekler için yeni bir sınıflama yapıldı. Bu sınıflamada; kasap, aşçı, çiftçi, laborant ve manavlar riskli meslek kategorisini oluşturdu. Ev hanımları herhangi bir meslek grubunda olmamasına

Tablo I. Anti-Toxoplasma Antikorlarının Referans Aralıkları

\begin{tabular}{lccc}
\hline & Non-reaktif & Sınırda & Reaktif \\
\hline Toksoplazma IgM & $<0.8 \mathrm{COI}$ & $\geq 0.8-<1.0 \mathrm{COI}$ & $\geq 1.0 \mathrm{COI}$ \\
Toksoplazma IgG & $1 \mathrm{IU} / \mathrm{ml}$ & $\geq 1-<3 \mathrm{IU} / \mathrm{ml}$ & $\geq 3 \mathrm{IU} / \mathrm{ml}$
\end{tabular}


rağmen, geleneksel olarak evde evcil hayvanlarla ilgilenmesi, evde yemek pişirmek için daha fazla zaman harcaması, eldiven giymeden çiğ etle teması, yemek hazırlama sırasında pişmemiş etlerin tadılması, çiğ sebze ve meyvelerle teması, özellikle bazı kırsal bölgelerde bahçe-tarla işleriyle uğraşması sebebiyle riskli meslekler sınıflamasına dahil edildi.

Katılımcıların kendi beyanlarına göre ağırlıkları $(\mathrm{kg})$, boylarının $(\mathrm{cm})$ karesine bölünerek Vücut Kitle Indeksi (VKi) hesaplandı. Hesaplanan VKi'lerin sınıflandırılmasında Dünya Sağlık Örgütü (DSÖ)'nün sınıflaması kullanıldı.

Araştırmaya katılanların gelir getirici iş durumu sorgulanırken, dört kategori kullanılmıştır. Bunlar; 'evet çalışıyorum', 'hayır işsizim', 'hayır öğrenciyim', 'hayır emekliyim' şeklindedir. Karşılaştırmalı analizlerde gelir getirici iş durumu evet ve hayır olarak gruplandırıldı.

Katılımcıların alışkanlıkları değerlendirilirken sigarayı hayatının herhangi bir zamanında kullanıp bırakanlar, kullananlarla beraber kategorize edildi. Hayatı boyunca hiç kullanmayanlar diğer grubu oluşturmaktadır. Alkol için de aynı kategorizasyon kullanıldı.

Eğitim durumu, lojistik regresyon modelinde iki gruba ayrıldı; ilkokul ve altı, ortaokul ve üstü şeklinde kategorize edildi.

\section{İstatistiksel Analiz}

Verilerin analiz aşamasında SPSS 23.0 istatistik paket programı kullanıldı. Değerlendirme sonuçlarının tanımlayıcı istatistikleri; kategorik değişkenler için sayı (n) ve yüzde (\%), sayısal değişkenler için ortalama (ort), standart sapma (ss), minimum (min), maksimum (maks) değerler olarak verildi. Bağımsız gruplarda kategorik değişkenlerin analizinde kikare testi kullanıldı. Toplanan tüm değişkenler için tek değişkenli analiz yapıldı ve $p<0.25$ değerine ulaşanlar çok değişkenli modele dahil edildi. Çok değişkenli analizde, önceki analizlerde belirlenen olası faktörler kullanılarak T.gondii enfeksiyonunu öngörmedeki bağımsız prediktörleri saptamak amacıyla lojistik regresyon analizi kullanıldı. İstatistiksel önemlilik seviyesi $\mathrm{p}<0.05$ olarak kabul edildi.

\section{BULGULAR}

Trabzon şehrinin 10 ilçesinden 1502 kişinin dahil edildiği çalışmada, katılımcıların 767 (\%51.1)'si kadın, 735 (\%48.9)'i erkek olup, yaş ortalamaları $45.7 \pm 16.9$ yıl olarak tespit edilmiştir. Katılımcıların sosyodemografik özelliklerine göre dağılımı Tablo II'de özetlenmiştir.

Çalışmaya katılan 1502 kişinin seropozitifliklerine bakıldığında 852 kişide (\%56.7) sadece IgG pozitif, 2 kişide ise (\%0.2) sadece IgM pozitif saptanmıştır. IgG pozitif ve/veya IgM pozitif kişi sayısı 886 (\%59.0) iken, iki anti-Toxoplasma antikorunun da birlikte pozitif olduğu kişi sayısı 32 (\%2.1) olarak bulunmuştur. 3 (\%0.2) kişide IgG sınırda tespit edilirken, 11 (\%0.7) kişide ise IgM "borderline" olarak raporlanmıştır. (Tablo III).

Katılımcıların bazı sosyodemografik özelliklerine göre anti-Toxoplasma seropozitifliklerinin dağılımları Tablo IV'te gösterilmiştir. Tabloya göre evli olanlarda, kırsal bölgede 


\begin{tabular}{|c|c|c|}
\hline Sosyodemografik özellikler $(n=1502)$ & $\mathbf{n}$ & $\%$ \\
\hline \multicolumn{3}{|l|}{ Cinsiyet $(n=1502)$} \\
\hline Kadın & 767 & 51.1 \\
\hline Erkek & 735 & 48.9 \\
\hline \multicolumn{3}{|l|}{ Medeni durum $(n=1502)$} \\
\hline Evli & 1080 & 71.9 \\
\hline Bekar & 412 & 28.1 \\
\hline \multicolumn{3}{|l|}{ Eğitim durumu $(n=1502)$} \\
\hline Okuryazar değil & 117 & 7.8 \\
\hline Okuryazar & 54 & 3.6 \\
\hline illkokul & 426 & 28.4 \\
\hline Ortaokul & 158 & 10.5 \\
\hline Lise & 434 & 28.9 \\
\hline Üniversite-Yüksekokul & 313 & 20.8 \\
\hline \multicolumn{3}{|l|}{ Yerleşim yeri $(n=1502)$} \\
\hline Kentsel & 854 & 56.9 \\
\hline Kırsal & 648 & 43.1 \\
\hline \multicolumn{3}{|l|}{ Kalabalık indeksi $(n=1502)$} \\
\hline$\geq 1$ & 817 & 54.4 \\
\hline $0.50-0.99$ & 547 & 36.4 \\
\hline$<0.50$ & 138 & 9.2 \\
\hline \multicolumn{3}{|l|}{ Gelir getirici iş varlığı $(n=1502)$} \\
\hline Evet & 618 & 41.1 \\
\hline Hayır, işsiz & 608 & 40.5 \\
\hline Hayır, emekli & 199 & 13.2 \\
\hline Hayır, öğrenci & 77 & 5.1 \\
\hline \multicolumn{3}{|l|}{ Meslek $(n=762)$} \\
\hline Profesyonel meslek grupları & 205 & 26.9 \\
\hline Nitelik gerektirmeyen işlerde çalışanlar & 146 & 19.2 \\
\hline Teknisyen/teknikerler & 101 & 13.3 \\
\hline Büro hizmetinde çalışanlar & 90 & 11.8 \\
\hline Şoför/makine operatörleri & 85 & 11.2 \\
\hline Hizmet ve satış elemanları & 64 & 8.4 \\
\hline Nitelikli tarım, orman, su ürünlerinde çalışanlar & 59 & 7.7 \\
\hline Gelir (Ort \pm SS, Min-Max) $(n=1502)$ & \multicolumn{2}{|c|}{$2963.9 \pm 2027.7(500-20000)$} \\
\hline
\end{tabular}

SS: Standart sapma, Min: Minimum, Max: Maksimum, Ort: Ortalama. 


\begin{tabular}{|c|c|c|c|}
\hline Toxoplasma belirteçleri & $\mathbf{n}$ & $\%$ & (\%95 Güven aralığı) \\
\hline Sadece $\lg G(+)$ & 852 & 56.7 & $(54.3-59.9)$ \\
\hline Sadece IgM (+) & 2 & 0.2 & $(0.0-0.3)$ \\
\hline IgG (+) ve/veya IgM (+) & 886 & 59.0 & $(56.7-61.5)$ \\
\hline $\lg G(+)$ ve $\lg M(+)$ birlikte & 32 & 2.1 & $(1.5-2.9)$ \\
\hline IgG borderline & 3 & 0.2 & $(0.0-0.5)$ \\
\hline IgM borderline & 11 & 0.7 & $(0.3-1.2)$ \\
\hline
\end{tabular}

yaşayanlarda, geliri 2000 TL altı olanlarda ve meslek grubu yüksek olanlarda seropozitiflik istatistiksel olarak önemli düzeyde yüksek $(p<0.05)$ olarak saptanmıştır. Yaş arttıkça ve eğitim düzeyi düştükçe seropozitifliğin arttığı belirlenmiştir $(p<0.001)$.

Bazı risk faktörlerine göre toksoplazmoz seroprevalanslarının dağılımı incelendiğinde, bahçe ve tarla işleriyle uğraşanlarda, hayvancılık yapanlarda, psikiyatrik hastalığı olanlarda ve diyabet öyküsü bulunanlarda seropozitiflik istatistiksel olarak önemli düzeyde yüksek bulunmuştur $(\mathrm{p}<0.05)$ (Tablo $\mathrm{V})$.

Anti-Toxoplasma seropozitifliğine etki eden faktörleri tespit etmek için yapılan lojistik regresyon modeline göre; yaş arttıkça seropozitifliğin arttığı $(p<0.001)$, Toxoplasma enfeksiyonun bahçe ve tarla işi ile uğraşanlarda daha fazla görüldüğü $(p=0.028)$ ve eğitim durumunun ilkokul ve altı olmasının anti-Toxoplasma seropozitifliğinde riski arttırıcı bir faktör olduğu bulunmuştur ( $p=0.016)$ (Tablo VI).

\section{TARTIŞMA}

Yürütülen bu kesitsel çalışmada, bireylerin \%59.0'unda anti-T.gondii IgM ya da IgG seropozitifliği bulunmuştur. Genel toplumda yapılan geniş bir katılımcı kitlesine sahip bu çalışma sonuçları dünyada yapılan çalışmalara göre görece daha yüksek bir seropozifliği ortaya koymuştur. Avrupa kıtasında yapılan çalışmalarda; toksoplazmoz seroprevalansı Batı Romanya'da ${ }^{12} \% 64.8$, Almanya'da ${ }^{13} \% 55$, Estonya'da ${ }^{14} \% 54.9$, Rusya' da ${ }^{15} \% 30.9$, Slovakya'da ${ }^{16} \% 24.2$, İsveç'te ${ }^{14} \% 23$ ve İzlanda'da ${ }^{14} \% 9.8$ olarak bildirilmiştir. Dünya genelinde ise, geniş bir yüzde aralığı göze çarpmaktadır. Anti-Toxoplasma seropozitifliği bir Afrika ülkesi olan Gana'da ${ }^{17} \% 85.0$, Etiyopya'da ${ }^{18} \% 65.8$ olarak bulunurken, Asya kıtasındaki Çin'de ${ }^{19} \% 21.6$, Güney Kore'de ${ }^{20} \% 8$, Kırgızistan'ın kırsalında ${ }^{21}$ ise \%6.2 olarak saptanmıştır. Asya'nın genelini kapsayan bir derlemede bu sıklık \%5-67 arası olarak raporlanmıştı ${ }^{22}$. Ülkeler arasındaki prevalans değişkenlikleri, coğrafi farklılıklar, ülkelerin sosyoekonomik durumları, kontamine et-toprak-su maruziyetinin farklı olması, çalışmalara dahil edilen yaş grubundaki değişkenlik ve uygulanan serolojik yöntemlerin duyarlılıklarındaki farklılıklardan kaynaklanabileceği düşünülmüştür. Literatürdeki bazı çalışmalar Tablo VII'de sunulmuştur.

Türkiye içindeki çalışmalara bakıldığında ise; Yolasığmaz ve arkadaşları ${ }^{10}$ İmir' de 7-50 yaş arası katılımcılarla yaptığı çalışmada seropozitifliği kırsal kesimde \%37.0, kentsel 
Tablo IV. Katılımcıların Bazı Sosyodemografik Özelliklerine Göre Toksoplazmoz Seroprevalanslarının Dağılımları

\begin{tabular}{|c|c|c|c|c|c|}
\hline \multirow{2}{*}{$\begin{array}{l}\text { Sosyodemografik } \\
\text { özellikler }(n=1502)\end{array}$} & \multirow{2}{*}{$\begin{array}{l}\text { Test edilen } \\
\text { kişi sayısı }\end{array}$} & \multicolumn{2}{|c|}{ Seropozitif } & \multirow[b]{2}{*}{ \%95 Güven aralığı } & \multirow[b]{2}{*}{ p } \\
\hline & & $\mathbf{n}$ & $\%$ & & \\
\hline \multicolumn{6}{|l|}{ Cinsiyet $(n=1502)$} \\
\hline Kadın & 767 & 452 & 58.9 & $55.5-62.7$ & \\
\hline Erkek & 735 & 434 & 59.0 & $55.5-62.2$ & 0.963 \\
\hline \multicolumn{6}{|l|}{ Medeni durum $(n=1502)$} \\
\hline Evli & 1080 & 695 & 64.4 & $61.7-67.3$ & \\
\hline Bekar & 412 & 191 & 45.3 & $40.5-50.0$ & $<0.001$ \\
\hline \multicolumn{6}{|l|}{ Yaş grupları $(n=1502)$} \\
\hline $20-29$ & 150 & 85 & 27.7 & 23.1-32.9 & \\
\hline $30-39$ & 152 & 146 & 47.6 & $42.0-52.8$ & \\
\hline $40-49$ & 142 & 170 & 60.5 & $54.8-65.8$ & \\
\hline $50-59$ & 130 & 198 & 75.3 & $70.3-80.6$ & \\
\hline $60-69$ & 100 & 158 & 82.7 & $77.5-88.0$ & \\
\hline 70 ve üzeri & 93 & 129 & 84.3 & $78.4-90.2$ & $<0.001^{*}$ \\
\hline \multicolumn{6}{|l|}{ Eğitim durumu $(n=1502)$} \\
\hline Okuryazar değil & 117 & 101 & 86.3 & $79.5-92.3$ & \\
\hline Okuryazar & 54 & 40 & 74.1 & $61.1-85.2$ & \\
\hline İlkokul & 426 & 313 & 73.5 & $69.0-77.0$ & \\
\hline Ortaokul & 158 & 86 & 54.4 & $46.8-62.0$ & \\
\hline Lise & 434 & 218 & 50.2 & $45.9-54.8$ & \\
\hline Üniversite & 313 & 128 & 40.9 & $35.2-47.0$ & $<0.001^{*}$ \\
\hline \multicolumn{6}{|l|}{ Yerleşim yeri $(n=1502)$} \\
\hline Kentsel & 854 & 475 & 55.6 & $52.1-59.0$ & \\
\hline Kırsal & 648 & 411 & 63.4 & $60.0-67.1$ & 0.002 \\
\hline \multicolumn{6}{|c|}{ Kalabalık indeksi $(n=1502)$} \\
\hline$\geq 1$ & 817 & 469 & 57.4 & $53.5-60.8$ & \\
\hline $0.50-0.99$ & 547 & 329 & 60.1 & $55.8-64.0$ & \\
\hline$<0.5$ & 138 & 88 & 63.8 & $55.1-71.7$ & 0.293 \\
\hline \multicolumn{6}{|l|}{ Gelir $(n=1502)$} \\
\hline 2000 TL ve altı & 757 & 510 & 67.4 & $64.1-71.1$ & \\
\hline 2000 TL üstü & 745 & 376 & 50.5 & $46.7-54.2$ & $<0.001$ \\
\hline \multicolumn{6}{|c|}{ Meslek grupları $(n=1282)$} \\
\hline Riski düşük olanlar & 799 & 397 & 49.7 & $51.3-57.4$ & \\
\hline Riski yüksek olanlar & 483 & 333 & 68.9 & $64.9-73.0$ & $<0.001$ \\
\hline
\end{tabular}

kesimde \%23.0 olarak saptamışlardır. Açıcı ve arkadaşlarının ${ }^{26}$ Samsun'da tarım iş̧̧ileri üzerinde yaptığı araştırmada anti-T.gondii seropozitifliği \%31.9 olarak belirtilmiştir. Çalışmamızdaki seropozitifliğin görece yüksek olması, çalışma grubunun 20 yaş üstü bireyler- 
Tablo V. Katılımcıların Bazı Risk Faktörlerine Göre Toksoplazmoz Seroprevalanslarının Dağıımı

\begin{tabular}{|c|c|c|c|c|c|}
\hline \multirow[b]{2}{*}{ Risk faktörleri ( $n=1502)$} & \multirow{2}{*}{$\begin{array}{l}\text { Test edilen } \\
\text { kişi sayısı }\end{array}$} & \multicolumn{2}{|c|}{ Seropozitif } & \multirow[b]{2}{*}{ \%95 güven aralığı } & \multirow[b]{2}{*}{$\mathbf{p}$} \\
\hline & & $\mathrm{n}$ & $\%$ & & \\
\hline \multicolumn{6}{|l|}{$\begin{array}{l}\text { Bahçe-tarla işleriyle uğraşma } \\
(n=1502)\end{array}$} \\
\hline Evet & 763 & 506 & 66.3 & $63.0-69.6$ & \\
\hline Hayır & 739 & 380 & 51.4 & $48.0-55.1$ & $<0.001$ \\
\hline \multicolumn{6}{|l|}{ Hayvancılık yapma $(n=1502)$} \\
\hline Evet & 212 & 145 & 68.4 & $62.3-74.5$ & \\
\hline Hayır & 1290 & 741 & 57.4 & $54.6-60.3$ & 0.003 \\
\hline \multicolumn{6}{|l|}{ Evde kedi besleme $(n=1502)$} \\
\hline Evet & 61 & 38 & 62.3 & $50.8-73.8$ & \\
\hline Hayır & 1441 & 848 & 58.8 & $56.2-61.6$ & 0.687 \\
\hline \multicolumn{6}{|c|}{$\begin{array}{l}\text { Çiğ ya da pişmemiş et tüketme } \\
(n=1502)\end{array}$} \\
\hline Evet & 273 & 166 & 60.8 & $54.9-66.7$ & \\
\hline Hayır & 1229 & 720 & 58.6 & $55.8-61.3$ & 0.500 \\
\hline \multicolumn{6}{|l|}{ Çiğ süt tüketimi $(n=1502)$} \\
\hline Evet & 437 & 248 & 56.8 & $52.4-61.6$ & \\
\hline Hayır & 1065 & 638 & 59.9 & $56.9-62.8$ & 0.259 \\
\hline \multicolumn{6}{|c|}{$\begin{array}{l}\text { Yıkanmamış çiğ meyve sebze tüketimi } \\
(n=1502)\end{array}$} \\
\hline Evet & 1410 & 836 & 59.3 & $56.8-61.7$ & \\
\hline Hayır & 92 & 50 & 54.3 & $43.5-64.1$ & 0.350 \\
\hline \multicolumn{6}{|c|}{ İşlenmemiş su kullanımı $(n=1502)$} \\
\hline Evet & 251 & 157 & 62.5 & $56.6-68.5$ & \\
\hline Hayır & 1251 & 729 & 58.3 & $55.6-61.0$ & 0.209 \\
\hline \multicolumn{6}{|c|}{ İmmünsupresif ilaç kullanımı $(n=707)$} \\
\hline Evet & 74 & 55 & 74.3 & $64.9-83.8$ & \\
\hline Hayır & 633 & 437 & 69.0 & $65.2-72.5$ & 0.422 \\
\hline \multicolumn{6}{|c|}{ Psikiyatrik hastalık varlığı $(n=1502)$} \\
\hline Evet & 323 & 216 & 66.9 & $61.6-71.8$ & \\
\hline Hayır & 1179 & 670 & 56.8 & $53.9-59.7$ & 0.001 \\
\hline \multicolumn{6}{|l|}{ Diyabet varlığı $(n=1502)$} \\
\hline Evet & 168 & 130 & 77.4 & $70.8-83.3$ & \\
\hline Hayır & 1334 & 756 & 56.7 & $54.0-59.4$ & $<0.001$ \\
\hline \multicolumn{6}{|l|}{ Kanser varlığı $(\mathrm{n}=1502)$} \\
\hline Evet & 27 & 7 & 74.1 & $70.8-83.3$ & \\
\hline Hayır & 1475 & 866 & 58.7 & $54.0-59.4$ & 0.158 \\
\hline \multicolumn{6}{|l|}{ Kemoterapi alma $(n=1502)$} \\
\hline Evet & 17 & 12 & 70.6 & $70.8-83.3$ & \\
\hline Hayır & 1485 & 874 & 58.9 & $54.0-59.4$ & 0.465 \\
\hline \multicolumn{6}{|l|}{ Radyoterapi alma $(\mathrm{n}=1502)$} \\
\hline Evet & 16 & 11 & 68.8 & $70.8-83.3$ & \\
\hline Hayır & 1486 & 875 & 58.9 & $54.0-59.4$ & 0.587 \\
\hline
\end{tabular}




\begin{tabular}{|c|c|c|c|c|}
\hline Değişkenler & $\beta$ & OR & \%95 Güven Aralığı & p \\
\hline Yaş & 0.048 & 1.05 & $1.04-1.06$ & $<0.001$ \\
\hline VKi & 0.021 & 1.02 & $1.00-1.05$ & 0.090 \\
\hline \multicolumn{5}{|l|}{ Eğitim durumu } \\
\hline İlkokul ve altı & 0.342 & 1.41 & $1.07-1.86$ & 0.016 \\
\hline Ortaokul ve üstü & & 1 & & \\
\hline \multicolumn{5}{|c|}{ Bahçe-tarla işleriyle uğraşma } \\
\hline Hayır & & 1 & & \\
\hline Evet & 0.271 & 1.31 & $1.03-1.67$ & 0.028 \\
\hline \multicolumn{5}{|l|}{ Hayvancilık } \\
\hline Hayır & & 1 & & \\
\hline Evet & 0.343 & 1.41 & $0.99-2.01$ & 0.057 \\
\hline
\end{tabular}

\begin{tabular}{|c|c|c|c|c|c|}
\hline Kaynak & Ülke & $\begin{array}{l}\text { Çalışma } \\
\text { Zamanı }\end{array}$ & $\begin{array}{l}\text { Örneklem } \\
\text { büyüklüŭğü } \\
(\mathrm{n})\end{array}$ & $\begin{array}{c}\text { Serolojik } \\
\text { test }\end{array}$ & $\begin{array}{c}\text { Seroprevalans } \\
(\%)\end{array}$ \\
\hline Wilking ve arkadaşları ${ }^{13}$ & Almanya & $2008-2011$ & 6564 & ELFA & 55.0 \\
\hline Jones ve arkadaşları ${ }^{23}$ & $A B D$ & 2009-2010 & 7072 & EIA & 13.2 \\
\hline Lim ve arkadaşları ${ }^{20}$ & Güney Kore & 2012 & 2150 & ELISA & 9.6 \\
\hline Minbaeva ve arkadaşları ${ }^{21}$ & Kırgızistan & 2012 & $\begin{array}{l}1,061 \text { kırsal } \\
899 \text { kentsel }\end{array}$ & ELISA & $\begin{array}{l}6.2 \text { kırsal } \\
19.0 \text { kentsel }\end{array}$ \\
\hline Almasian ve arkadaşları ${ }^{24}$ & İran & 2013 & 1000 & IFA & 16.9 \\
\hline Li ve arkadaşları ${ }^{19}$ & Çin & 2013 & 1150 & ELISA & 21.6 \\
\hline Abu ve arkadaşları ${ }^{17}$ & Gana & 2014 & 390 & ELISA & 85.0 \\
\hline $\begin{array}{l}\text { De Almeida Aloise ve } \\
\text { arkadaşları }^{25}\end{array}$ & Brezilya & 2017 & 1540 & ELISA & 66.2 \\
\hline
\end{tabular}

den oluşmasına ve çalışmanın gerçekleştirildiği Trabzon ilinin coğrafi koşullarından dolayı nemli bir havaya sahip olmasına bağlanabilir.

Bu çalışmada, birçok değişkenin tek değişkenli analizde T.gondii enfeksiyonu ile ilişkili olduğu bulunmuştur (Tablo IV ve Tablo V). Çok değişkenli lojistik regresyon analizinde ise yaş, eğitim durumu ve bahçe-tarla işleriyle uğraşma potansiyel risk faktörü olarak saptanmıştır (Tablo VI). Yaş arttıkça parazitle karşılaşma olasıllığı arttığından ve bağışıklığın azalmasından dolayı anti-T.gondii seropozitifliğinin arttığı kabul edilmektedir. Bu çalışmada da yaş arttıkça seroprevalans artmaktadır. Yaş grupları açısından bakıldığında 20-29 yaş grubunda \%27.7 pozitiflik saptanmışken, 70 yaş üzeri grupta bu oran artarak \%84.3'e 
yükselmiştir. İstatiksel olarak önemli olan bu artış, uluslararası yapılan çalışmalarla paralellik göstermektedir. Güney Kore' de $^{20}$ yapılan çalışmada 40 yaş üzeri katılımcılarda, Brezilya' $\mathrm{da}^{25}$ yapılan çalışmada 45 yaş üzeri bireylerde seroprevalans yüksek bulunmuştur. Batı Romanya'da ${ }^{12}$, Gana'da ${ }^{17}$, ABD' $^{\prime 23}$ yapılan çalışmalarda yaş arttıkça pozitiflik oranlarının arttığı saptanmıştır .

Eğitim düzeyi Toxoplasma enfeksiyonunda belirleyici faktörlerden biridir. Birçok epidemiyolojik çalışma düşük eğitim düzeyinin T.gondii enfeksiyonu ile karşılaşma riskini artırdığını göstermiştir ${ }^{25,27}$. Bu çalışmadaki veriler de literatürdeki diğer çalışmalarla paralellik göstermektedir. Eğitim durumunun ortaokul ve üzeri olması lojistik regresyon analizinde bağımsız bir riski azaltıcı faktör olarak karşımıza çıkmaktadır. Eğitim durumu kişilerin Toxoplasma enfeksiyonu hakkındaki bilgilerini yansıtıyor olabilir. Eğitim durumu arttıkça kişisel hijyen bilgisinin de artması enfeksiyonun daha az görülmesinde rol alabilir. Bahçe ve tarla işleriyle uğraşan, toprakla teması oluşan kişiler Toxoplasma enfeksiyonu açısından risk altındadır. Avrupa'da ${ }^{28}$ çok merkezli yapılan araştırmaya katılanlarda 1.81 kat, Gana'da ${ }^{17}$ toplum tabanlı yapılan çalışmada ise 38.4 kat enfeksiyon riskini artırdığı rapor edilmiştir. Literatürdeki çoğu çalışma ile uyumlu bulunan bu değişken, lojistik regresyon analizinde bağımsız bir risk faktörü olarak da karşımıza çıkmaktadır.

Çalışmamızda Toxoplasma enfeksiyonu cinsiyetler arasında farklılık göstermemektedir. İran'da ${ }^{29}$ yapılan bir metaanalizde ve Slovakya' da ${ }^{16}$ yapılan araştırmalarda bizim çalışmamızda olduğu gibi kadın ve erkek cinsiyetleri arasında önemli bir fark saptanmamıştır. Yerleşim yerleri açısından bakıldığında, kırsal bölgelerde yaşayanlarda anti-Toxoplasma seropozitifliği daha fazladır. İran'da kan bağış̧̧ılarında yapılan çalışmada kırsal kesimde yaşayanlarda enfeksiyon riskinin iki kat fazla olduğu bulunmuştur ${ }^{30}$. Romanya'da yapılan bir başka araştırmada kırsal kesimde ikamet edenlerdeki seropozitiflik, kentte yaşayanlara göre daha fazla saptanmıştır ${ }^{12}$. Buna karşın yerleşim yerine göre farklılık bulmayan çalışmalar da literatürde mevcuttur ${ }^{16}$. Tam zıt olarak; Kırgızistan'da yapılan araştırmada ise kentte yaşayanlarda seropozitiflik daha yüksek bulunmuştur. Bu durum kırsal kesimde çiğ et tüketiminin az olması ile açıklanmıştır ${ }^{21}$. Mevcut çalışmada, bahçe-tarla gibi toprakla temasın daha fazla olması ve hayvancılıkla daha çok uğraşılmasının yanında eğitim seviyesinin daha düşük olması kırsal alandaki seropozitifliğin daha fazla olmasını açıklayabilir. Ayrıca, her ülkede kırsal ve kentsel tanımları da değişmektedir. Bu durum da dikkate alınmalıdır.

Toxoplasma gondii ile ilgili yapılan çalışmalar enfeksiyonda kedilerin son konak olduğunu ve enfeksiyonun yayılmasında kedilerin varlığının önemli bir rol oynadığını göstermektedir ${ }^{2}$. Bu konu hakkında literatürde birçok çalışma bulunmaktadır ${ }^{17,31}$. Farklı olarak bu çalışmada evinde kedi bulunduranlarla bulundurmayanlar arasında seropozitiflik açısından önemli bir fark bulunmamıştır. Çalışmamızda evinde kedi besleyenlerin sayıca az olması (\%4.1), ev kedilerinin sokak kedilerine göre enfeksiyon açısından daha az risk taşıması olası sebepler olarak düşünülebilir. Bazı araştırmalar beslenme alışkanlıkları ile yakından ilişkili olan Toxoplasma enfeksiyonunda çiğ et tüketiminin rolü olduğunu göstermektedir $^{32}$. Bizim çalışmamızda çiğ et tüketimi olan katılımcılarla çiğ et tüketmeyenler arasında istatistiksel düzeyde önemli fark bulunmamıştır. Ülkeler arası dini ve kültürel 
sebeplerle tüketilen et türlerinin değişkenlik göstermesi ve eti pişirmedeki farklııklar sonuçlardaki çeşitliliğin nedeni olabilir.

Son zamanlarda yapılan çalışmalarda Helicobacter pylori ve Coxsakie B4 virus gibi enfeksiyöz ajanların diyabet ile ilişkili bulunmaları T.gondii'nin de diyabet için muhtemel bir neden olabileceğini düşündürmüşsür ${ }^{33}$. Kore'de hastaneye başvuran 1265 kişi üzerinde yapılan çalışmada anti-Toxoplasma seropozitifliğinin diyabetle ilişkili olabileceği sonucuna varılmıştır ${ }^{34}$. Avustralya'da yayımlanan derlemede araştırmacılar "toksoplazmik tip 2 diyabet" adında yeni bir çalışma alanı önermişlerdir ${ }^{35}$. Çalışmamızda diyabet hastalarındaki seropozitiflik oranı, diyabet olmayanlara göre istatistiksel olarak önemli düzeyde yüksektir (Tablo V). Ortaya çıkan bu ilişkinin mekanizmasının ileri çalışmalarla ortaya konulması gerekmektedir.

Günümüzde araştırmacıların yoğunlaştığı konulardan birisi de psikiyatrik hastalıklarla Toxoplasma enfeksiyonu arasındaki ilişkinin ortaya konmasıdır. Toxoplasma enfeksiyonunun insan davranışlarını ve kişilik özelliklerini değiştirebileceği düşünülmektedir ${ }^{36}$. Tam tersine bir durum da söz konusu olabilir. Psikiyatrik hastalığı olanlarda yeme ve hijyen alışkanlıklarının değişebileceği akılda tutulmalıdır. Sutterland ve arkadaşlarının ${ }^{37}$ yaptığı sistematik derleme ve meta-analizde, şizofrenide 1.81 kat, bipolar bozuklukta 1.52 kat, obsesif-kompulsif bozulukta 3.4 kat fazla anti-Toxoplasma-lgG antikorları saptanmıştır. Bizim çalışmamızda psikiyatrik hastalığı bulunan katılımcılarda anti-Toxoplasma seropozitifliği istatistiksel olarak önemli düzeyde fazladır (Tablo V). Bu sonuçlar literatürle uyumluluk göstermektedir. Nedensel ilişkinin ortaya konulabilmesi için ileri çalışmalara ihtiyaç vardır.

\section{Sınırlılıklar}

Bu çalışmada bazı verilerin beyana göre alınması en büyük sınırlılık olarak göze çarpmaktadır. Katılımcıların boy ve kiloları ölçülmemiş, boy ve kiloları ile hastalık durumları sorgulanırken kendi beyanları esas alınmıştır. Diğer bir sınırlılık ise meslek grubu sınıflandırmasında yaşanmıştır. Meslek grubu, riskli ve riskli olmayan meslekler olarak ikiye ayrılmasına rağmen, riskli olmayan meslek grubundaki kişilerin Toxoplasma enfeksiyonuna yol açabilecek işlerle uğraşması (örneğin; bahçe ve tarla işleri) önemli bir sınırlılık oluşturmaktadır. Sadece lgM pozitifliği olan vakaların (2 kişi) yalancı pozitifliği ya da akut enfeksiyonu gösterebileceği düşünüldüğünden tekrar test yapılmış, sonuç yine IgM pozitif gelince seropozitif kabul edilmiştir.

Toplum tabanlı gerçekleştirilen bu çalışmada, literatürdeki diğer toplum tabanlı çalışmalara göre yüksek seropozitiflik bulunmuştur. Eğitim durumu düşük olanlarda, bahçe ve tarla işleriyle uğraşanlarda seropozitifliğin yüksek görülmesi Toxoplasma gondii paraziti hakkındaki eğitimin önemini ortaya koymaktadır. Diyabetik ve psikiyatrik hastalıklarla ilgilenen klinisyenlerin toksoplazmozu da dikkate almaları gerekmektedir.

\section{ETIK KURUL ONAYI}

Bu çalışma, Karadeniz Teknik Üniversitesi Tıp Fakültesi Bilimsel Araştırmalar Etik Kurulu onayı ile gerçekleştirildi (Tarih: 05.12.2017 ve Karar No: 164). 


\section{ÇIKAR ÇATIŞMASI}

\section{Bu çalışma ile ilgili olarak çıkar çatışması bildirilmemiştir.}

\section{KAYNAKLAR}

1. Montoya JG, Boothroyd JC, Kovacs JA. Toxoplasma gondii. In: Bennett JE, Dolin R, Blaser MJ, editors. Mandell, Douglas, and Bennett's Principles and Practice of Infectious Disease $8^{\text {th }}$ ed. Philadelphia 2015; 3122-53.

2. Frenkel JK, Dubey JP, Miller NL. Toxoplasma gondii in cats: fecal stages identified as Coccidian Oocysts. Science 1970; 167(3919): 893-6.

3. Dubey JP. Toxoplasmosis - a waterborne zoonosis. Vet Parasitol 2004; 126(1-2): 57-72.

4. Frenkel JK. Pursuing Toxoplasma. J Infect Dis 1970; 122(6): 553-9.

5. Liu Q, Wang Z-D, Huang S-Y, Zhu X-Q. Diagnosis of toxoplasmosis and typing of Toxoplasma gondii. Parasit Vectors 2015; 8(1): 292.

6. Weiss LM, Dubey JP. Toxoplasmosis: a history of clinical observations. Int J Parasitol 2009; 39(8): 895-901.

7. Molan A, Nosaka K, Hunter M, Wang W. Global status of Toxoplasma gondii infection: systematic review and prevalence snapshots. Trop Biomed 2019: 36(4): 898-925.

8. Bigna JJ, Tochie JN, Tounouga DN, Bekolo AO, Ymele NS, Youda EL, et al. Global, regional, and country seroprevalence of Toxoplasma gondii in pregnant women: a systematic review, modelling and meta-analysis. Scientific Rep 2020; 10(1): 1-10.

9. Koloren Z, Dubey JP. A review of toxoplasmosis in humans and animals in Turkey. Parasitol 2020; 147(1): 12-28.

10. Yolasigmaz A, Sakru N, Yazar S, Akisu C, Guruz AY, Kuman HA, et al. Investigation of anti-Toxoplasma Antibodies in residence of urban and rural areas. Acta Parasitol Turcica 2003; 27(2): 81-4.

11. Liesenfeld O, Press C, Montoya JG, Gill R, Isaac-Renton JL, Hedman K, et al. False-positive results in immunoglobulin $\mathrm{M}$ (IgM) Toxoplasma antibody tests and importance of confirmatory testing: the platelia toxo IgM test. J Clin Microbiol 1997; 35(1): 174-8.

12. Olariu TR, Petrescu C, Darabus G, Lighezan R, Mazilu O. Seroprevalence of Toxoplasma gondii in Western Romania. Infect Dis (Lond) 2015; 47(8): 580-3.

13. Wilking $H$, Thamm M, Stark K, Aebischer T, Seeber F. Prevalence, incidence estimations, and risk factors of Toxoplasma gondii infection in Germany: a representative, cross-sectional, serological study. Sci Rep 2016; 6: 22551.

14. Birgisdottir A, Asbjornsdottir H, Cook E, Gislason D, Jansson C, Olafsson I, et al. Seroprevalence of Toxoplasma gondii in Sweden, Estonia and Iceland. Scand J Infect Dis 2006; 38(8): 625-31.

15. Shuralev EA, Shamaev ND, Mukminov MN, Nagamune K, Taniguchi Y, Saito T, et al. Toxoplasma gondii seroprevalence in goats, cats and humans in Russia. Parasitol Int 2018; 67(2): 112-4.

16. Studeničová C, Benčaiová G, Holková R. Seroprevalence of Toxoplasma gondii antibodies in a healthy population from Slovakia. Eur J Int Med 2006; 17(7): 470-3.

17. Abu EK, Boampong JN, Ayi I, Ghartey-Kwansah G, Afoakwah R, Nsiah P, et al. Infection risk factors associated with seropositivity for Toxoplasma gondii in a population-based study in the Central Region, Ghana. Epidemiol Infect 2015; 143(9): 1904-12.

18. Tilahun B, Hailu Y, Tilahun G, Ashenafi H, Vitale M, Di Marco V, et al. Seroprevalence and risk factors of Toxoplasma gondii infection in humans in East Hararghe Zone, Ethiopia. Epidemiol Infect 2016; 144(1): 64-71.

19. Li HL, Dong L, Li Q, Zhang L, Chen J, Zou FC, et al. Seroepidemiology of Toxoplasma gondii infection in Bai and Han ethnic groups in southwestern China. Epidemiol Infect 2015; 143(4): 881-6.

20. Lim H, Lee S-E, Jung B-K, Kim M-K, Lee MY, Nam H-W, et al. Serologic survey of Toxoplasmosis in Seoul and Jeju-do, and a brief review of its seroprevalence in Korea. The Korean J Parasitol 2012; 50(4): 287-93. 
21. Minbaeva G, Schweiger A, Bodosheva A, Kuttubaev O, Hehl AB, Tanner I, et al. Toxoplasma gondii infection in Kyrgyzstan: seroprevalence, risk factor analysis, and estimate of congenital and AIDS-related toxoplasmosis. PLoS Negl Trop Dis 2013; 7(2): e2043.

22. Khan MU, Rashid I, Akbar H, Islam S, Riaz F, Nabi H, et al. Seroprevalence of Toxoplasma gondii in South Asian countries. Rev Sci Tech-Off Int Des Epizoot 2017; 36(3): 981-96.

23. Jones JL, Kruszon-Moran D, Rivera HN, Price C, Wilkins PP. Toxoplasma gondii seroprevalence in the United States 2009-2010 and comparison with the past two decades. Am J Trop Med Hyg 2014; 90(6): 1135-9.

24. Almasian R, Almasian M, Zibaei M. Sero-Epidemiology of toxoplasmosis among the people of Khorram Abad, Iran. J Infect Dis Ther 2014; 2(5): 1-3.

25. De Almeida Aloise D, Coura-Vital W, Carneiro M, Venâncio Rodrigues M, Acásia da Silva Toscano G, Bernardino da Silva R, et al. Seroprevalence and risk factors for human toxoplasmosis in Northeastern Brazil. Rev Patol Trop 2017; 46(4): 307.

26. Acici M, Babur C, Kilic S, Hokelek M, Kurt M. Prevalence of antibodies to Toxoplasma gondii infection in humans and domestic animals in Samsun Province, Turkey. Trop Anim Health Prod 2008; 40(5): 311-5.

27. Hamidi M, Khulojini M, Azizian R, Bashiri H, Ahanchian A, Babanejad M, et al. Seroprevalence of toxoplasmosis among women referring to Shahid Beheshti Hospital, Hamadan, Iran. Novel Biomed 2015; 3(1): 1-5.

28. Cook AJC, Holliman R, Gilbert RE, Buffolano W, Zufferey J, Petersen E, et al. Sources of Toxoplasma infection in pregnant women: European Multicentre Case-Control Study. European Research Network on Congenital Toxoplasmosis. BMJ 2000; 321(7254): 142.

29. Daryani A, Sarvi S, Aarabi M, Mizani A, Ahmadpour E, Shokri A, et al. Seroprevalence of Toxoplasma gondii in the Iranian general population: a systematic review and meta-analysis. Acta Trop 2014; 137: 185-94.

30. Mahmoudvand H, Saedi Dezaki E, Soleimani S, Baneshi MR, Kheirandish F, Ezatpour B, et al. Seroprevalence and risk factors of Toxoplasma gondii infection among healthy blood donors in South-East of Iran. Parasite Immunol 2015; 37(7): 362-7.

31. Alvarado-Esquivel C, Mercado-Suarez MF, Rodriguez-Briones A, Fallad-Torres L, Ayala-Ayala JO, NevarezPiedra LJ, et al. Seroepidemiology of Infection with Toxoplasma gondii in Healthy Blood Donors of Durango, Mexico. BMC Infect Dis 2007; 13(7): 75.

32. Sakikawa M, Noda S, Hanaoka M, Nakayama H, Hojo S, Kakinoki S, et al. Anti-Toxoplasma antibody prevalence, primary infection rate, and risk factors in a study of toxoplasmosis in 4,466 pregnant women in Japan. Clin Vaccine Immunol CVI 2012; 19(3): 365-7.

33. Majidiani H, Dalvand S, Daryani A, Galvan-Ramirez ML, Foroutan-Rad M. Is chronic toxoplasmosis a risk factor for diabetes mellitus? A systematic review and meta-analysis of case-control studies. Braz J Infect Dis 2016; 20(6): 605-9.

34. Shin DW, Cha DY, Hua QJ, Cha GH, Lee YH. Seroprevalence of Toxoplasma gondii infection and characteristics of seropositive patients in general hospitals in Daejeon, Korea. Korean J Parasitol 2009; 47(2): 125-30.

35. Molan A, Nosaka K, Hunter M, Wang W. The role of Toxoplasma gondii as a possible inflammatory agent in the pathogenesis of type 2 diabetes mellitus in humans. Fam Med Commun Health 2016; 4(4): 44-62.

36. Hinze-Selch D, Däubener W, Erdag S, Wilms S. The diagnosis of a personality disorder increases the likelihood for seropositivity to Toxoplasma gondii in psychiatric patients. Folia parasitologica 2010; 57(2): 129-35.

37. Sutterland AL, Fond G, Kuin A, Koeter MW, Lutter R, van Gool T, et al. Beyond the association. Toxoplasma gondii in schizophrenia, bipolar disorder, and addiction: systematic review and meta-analysis. Acta Psychiatr Scand 2015; 132(3): 161-79. 